\begin{abstract}
"Mircea cel Batran" Naval Academy Scientific Bulletin, Volume XIX - 2016 - Issue 1
Published by "Mircea cel Batran" Naval Academy Press, Constanta, Romania /I The journal is indexed in:

PROQUEST / DOAJ / DRJI / JOURNAL INDEX / I2OR / SCIENCE LIBRARY INDEX / Google Scholar / Crossref /

Academic Keys I ROAD Open Access / OAJI / Academic Resources / Scientific Indexing Services / SCIPIO
\end{abstract}

\title{
PROVIDING FINANCIAL SUPPORT FOR THE NATIONAL DEFENSE SYSTEM IN THE CURRENT GEOPOLITICAL CONTEXT
}

\author{
Vasile DINU ${ }^{1}$ \\ Cristina-Mihaela LAZAR ${ }^{2}$ \\ Ionel BOSTAN ${ }^{3}$ \\ Costica ROMAN ${ }^{4}$ \\ Puiu NISTOREANU 5 \\ Ion-Stelian CHIHAI ${ }^{6}$ \\ ${ }^{1}$ Professor PhD, Academy of Economic Studies, Faculty of Commerce, Bucharest \\ ${ }^{2}$ Professor PhD, "Ovidius" University Constanta, Faculty of Economics and Business Administration \\ ${ }^{3}$ Professor PhD, "Alexandru loan Cuza" University lași, Centre for European Studies \\ ${ }^{4}$ Professor PhD, "Ștefan cel Mare" University, Faculty of Economics and Public Administration, Suceava \\ ${ }^{5}$ Professor PhD, Academy of Economic Studies, Faculty of Commerce, Bucharest \\ ${ }^{6}$ Professor PhD, "Ștefan cel Mare" University, Faculty of Economics and Public Administration, Suceava
}

\begin{abstract}
This paper highlights the most important aspects, seen mainly from an economic and financial perspective, of the correlation between the needs of the national defense system with the possibilities conferred by the development stage of our country, considering that Romania is a NATO member, with certain commitments in this regard. Obviously, based on the recent Political Agreement on increasing national defense funding, we consider that the support for military expenditure should be much stronger, given the risks of the current regional geopolitical space, generating instability and insecurity. Thus, after a period when the Romanian Army funding parameters were relatively modest, we highlight that the allocations in question are going to be based on a distribution of approx. 2\% of the GDP (period 20172027), a vital issue in ensuring the support and development of procurement programs - with equipment and combat technology - and military staff training. The study of the literature has strengthened our belief, expressed herein, that the respective percentage may be increased, depending on the security needs and obligations that Romania can assume, targeting - ultimately - a greater increase in the operational capability of the Army.
\end{abstract}

Keywords: public spending, military logistics/ procurement, remuneration/ pay, missions / operations.

\section{Introduction}

The early twenty-first century is marked by phenomena such as international migration, social tensions and conflicts, terrorism, dangers and threats, in the field of defense. The central focus in the current context falls on security, particularly for seeking and holding the necessary resources in order to control these phenomena, which depend, primarily, on several factors of economic nature.

Romania's status of full member in NATO structures and in the European space imposed transformations on the entire society, in general, and on the national defense system, in particular. Membership in these structures, and in others, must determine the responsible fulfillment of the role and obligations deriving from it; for this purpose, the defense sector needs a certain level of financial allocations. The defense system transformation into a modern structure depends on the budgetary allocation, which should allow the achievement of planned objectives and the compliance with the deadlines for providing the capabilities assumed.

Planning financial resources for defense is directly related to the governmental program, taking into account the provisions contained in the White Paper on Defense (Government of Romania, 2013) and the risks to which Romania is exposed, due to the current regional geopolitical context, generating instability and insecurity, and the challenges that it faces.

Recent assessments performed within the Ministry of National Defense (MApN, 2015), on the operational capacity of the Romanian Army, showed "the need for further structural and qualitative change, involving important budgetary, organizational and social efforts", especially since it aims at "achieving the final operational capacity of the two command-control structures in Romania, and continuing the rising trend of the frequency and intensity of the exercise in bilateral (Atlantic Resolve) or multinational format, both in Romania and on the territory of other allies". 


\begin{abstract}
"Mircea cel Batran" Naval Academy Scientific Bulletin, Volume XIX - 2016 - Issue 1
Published by "Mircea cel Batran" Naval Academy Press, Constanta, Romania /I The journal is indexed in:

PROQUEST / DOAJ / DRJI / JOURNAL INDEX I I2OR / SCIENCE LIBRARY INDEX / Google Scholar / Crossref I

Academic Keys I ROAD Open Access / OAJI / Academic Resources / Scientific Indexing Services / SCIPIO
\end{abstract}

Moreover, the program of transformation, develop ment and procurement of the Romanian Army until 2027 and in perspective (CSAT, 2015) reflects the provisions of the Political National Agreement on increasing funding for national defense (Romanian Presidency, 2015). The implementation of the program aims at ensuring the modernization of the Army's procurement, increasing the training level and the operational status of equipments and replenishing combat stocks.

On the other hand, aiming at achieving a NATO compatible force structure, the implementation of Target Capabilities 2013 - assumed by Romania at NATO, in the planning process of ally defense has become a priority, agreeing, at the same time (CSAT, 2013) to implement the new target capabilities, for 2015-2024.

In order to increase the operational capacity of the Army and to host the NATO contingents participating in exercises and applications within the Action Plan for achieving the operational capacities of the Alliance, the public investment policy was recently adapted. We notice, therefore, that its priority projects are related to the provision of logistical components such as (MApN, 2015): fighting machines on wheels and tracks; light armored and unarmored SUVs; multifunctional transport platforms; brigade and battalion command points; "Multirole Aircraft of the Air Force"; Aircraft safety equipment; Aerial surveillance systems and systems of groundbased air defense etc.

Obviously, the efforts made in order to increase the operational capacity of the structures of the
Romanian Army and the achievement of the tasks incumbent under the plans at Allied level and at national level, amid mission requirements and the application of NATO standards, can be approached from multiple angles and, certainly, much deeper. However, through our modest endeavor, carried forward, we came up with some data and remarks related to the provision of the financial support for the national defense system, in the current geopolitical context. However, we also wanted to reveal several important aspects, seen mainly from an economic and financial perspective, noting that the establishment of national defense needs should take into account the possibilities conferred by the country's development stage.

2. Analysis of the impact indicators on defense expenditures across several NATO countries

We conducted within this paper a study that took into account several NATO countries in terms of the evolution of some expenditure categories, reflected by the data below, for 2008-2015. The percentages and amounts underlying our analysis correspond to the NATO definition of "defense expenditures", "defense expenditures as a percentage of the GDP", "defense expenditure per capita", "distribution of defense expenditures by major categories"; these definitions and, therefore, the amounts may be different in national reports (NATO, 2016).

The amounts shown in the table below (Table no. 1) represent the defense expenditures incurred in the respective fiscal year, in million US dollars, during 2008-2015.

Table no. 1. Defense expenditures - Romania compared to other countries and NATO - Europe (2008-2015)

- mil. US dollars -

\begin{tabular}{|c|r|r|r|r|r|r|r|r|}
\hline $\begin{array}{c}\text { Country/milli } \\
\text { on US } \\
\text { dollars }\end{array}$ & 2008 & 2009 & 2010 & 2011 & 2012 & 2013 & 2014 & $2015 \mathrm{e}$ \\
\hline Bulgaria & 1.107 & 872 & 832 & 675 & 685 & 751 & 689 & 643 \\
\hline France & 60.791 & 52.465 & 51.971 & 50.439 & 50.721 & 50.721 & 50.173 & 49.735 \\
\hline Germany & 44.572 & 45.599 & 46.255 & 45.378 & 46.692 & 43.745 & 43.193 & 43.318 \\
\hline Italy & 31.561 & 29.769 & 28.656 & 27.746 & 25.853 & 24.535 & 22.129 & 19.391 \\
\hline Latvia & 437 & 298 & 251 & 257 & 232 & 251 & 259 & 300 \\
\hline Lithuania & 475 & 392 & 326 & 312 & 309 & 324 & 385 & 508 \\
\hline Romania & 3.626 & 2.251 & 2.086 & 2.180 & 2.090 & 2.264 & 2.458 & 2.704 \\
\hline $\begin{array}{c}\text { Slovak } \\
\text { Republic }\end{array}$ & 1.316 & 1.293 & 1.138 & 999 & 1.022 & 934 & 964 & 1.124 \\
\hline Slovenia & 767 & 754 & 772 & 627 & 553 & 494 & 471 & 469 \\
\hline $\begin{array}{c}\text { United } \\
\text { Kingdom }\end{array}$ & 60.350 & 59.505 & 60.329 & 59.319 & 54.438 & 58.139 & 57.394 & 55.387 \\
\hline $\begin{array}{c}\text { NATO - } \\
\text { Europe }\end{array}$ & 288,20 & 278,637 & 274,592 & 285,78 & 260,727 & 257,408 & 254,036 & 253,151 \\
\hline
\end{tabular}

Source: NATO (2016), Financial and Economic Data Relating to NATO Defense, NATO Public Diplomacy Division, available at 368 
"Mircea cel Batran" Naval Academy Scientific Bulletin, Volume XIX - 2016 - Issue 1

Published by "Mircea cel Batran" Naval Academy Press, Constanta, Romania /I The journal is indexed in:

PROQUEST / DOAJ / DRJI / JOURNAL INDEX / I2OR / SCIENCE LIBRARY INDEX / Google Scholar / Crossref /

Academic Keys I ROAD Open Access / OAJI / Academic Resources / Scientific Indexing Services / SCIPIO

http://www.nato.int/nato static fl2014/assets/pdf/pdf 2015 06/20150622 PR CP 2015 093-v2.pdf

For a better eloquence, based on the same data presented in the table above, we present the graphical representation of the evolution of the costs involved (Figure no. 1).

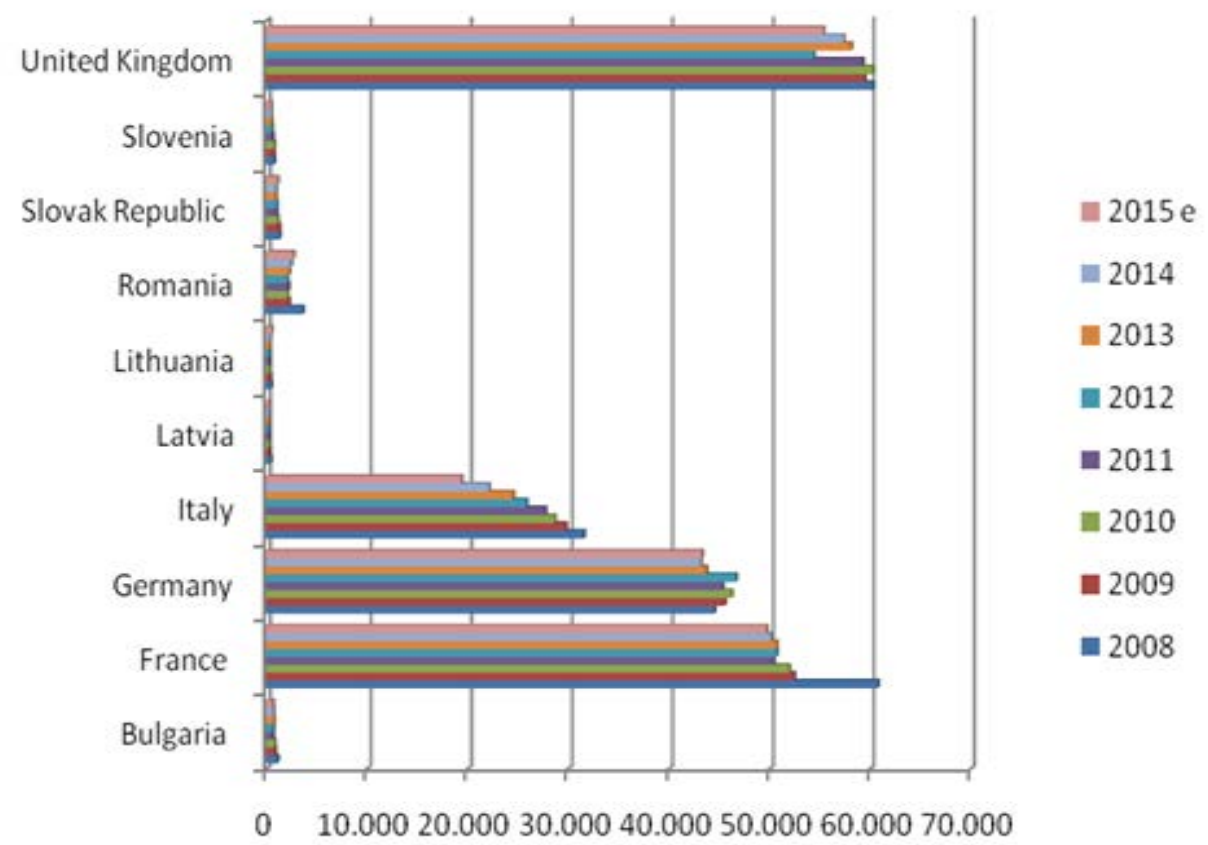

Figure no. 1. Defense expenditures - Romania compared to other countries and NATO - Europe (2008-2015)

Source: Drafted by authors, based on data released by NATO (2016), Financial and Economic Data Relating to NATO Defense, NATO Public Diplomacy Division, available at:

http://www.nato.int/nato static fl2014/assets/pdf/pdf 2015 06/20150622 PR CP 2015 093-v2.pdf

The evolution presented above, regarding the amounts budgeted to defense expenditures, reveal a great gap between countries such as the UK, France, Germany, Italy, the main supporters of NATO, and other countries under discussion, from Eastern Europe, including Romania.

Moreover, it is noteworthy that the values recorded in 2015 are below those recorded in 2008 for almost all countries under discussion, ascertaining a decrease in defense expenditures, from one year to another. However, it should be emphasized that these expenditures decreased in the United Kingdom from 60,350 million US dollars to 55,387 million US dollars, while in the case of Bulgaria, the last ranked, defense expenditures decreased from 1,107 million US dollars to 643 million US dollars.

The analysis of these data have revealed that one cannot compare the financial situation of the United Kingdom, Germany, France - the main top actors in achieving international security, in terms of these expenditures - with the economic power of the countries situated at the end of the ranking. A better image is provided by the analysis of the data in connection to the states' GDP and the expenditures per capita (Table no. 2). The lowest fixed amounts in this category of expenditures belong to states such as Lithuania and Latvia.

Table no. 2. Defense expenditures as a percentage of the gross domestic product

\begin{tabular}{|c|c|c|c|c|c|c|c|c|}
\hline Country & 2008 & 2009 & 2010 & 2011 & 2012 & 2013 & 2014 & $\begin{array}{c}2015 \\
\mathrm{e}\end{array}$ \\
\hline Bulgaria & 2,13 & 1,75 & 1,67 & 1,33 & 1,35 & 1,46 & 1,32 & 1,20 \\
\hline France & 2,27 & 2,02 & 1,96 & 1,87 & 1,87 & 1,86 & 1,84 & 1,8 \\
\hline Germany & 1,28 & 1,39 & 1,35 & 1,28 & 1,31 & 1,23 & 1,19 & 1,18 \\
\hline Italy & 1,43 & 1,42 & 1,35 & 1,30 & 1,24 & 1,20 & 1,09 & 0,95 \\
\hline Latvia & 1,52 & 1,21 & 1,06 & 1,02 & 0,89 & 0,93 & 0,94 & 1,06 \\
\hline
\end{tabular}

369 
"Mircea cel Batran" Naval Academy Scientific Bulletin, Volume XIX - 2016 - Issue 1

Published by "Mircea cel Batran" Naval Academy Press, Constanta, Romania /I The journal is indexed in:

PROQUEST / DOAJ / DRJI / JOURNAL INDEX I I2OR / SCIENCE LIBRARY INDEX / Google Scholar / Crossref /

Academic Keys / ROAD Open Access / OAJI / Academic Resources / Scientific Indexing Services / SCIPIO

\begin{tabular}{|c|c|c|c|c|c|c|c|c|}
\hline Lithuania & 1,11 & 1,07 & 0,88 & 0,79 & 0,76 & 0,76 & 0,88 & 1,14 \\
\hline Romania & 1,44 & 1,33 & 1,24 & 1,28 & 1,22 & 1,28 & 1,35 & 1,44 \\
\hline $\begin{array}{c}\text { Slovak } \\
\text { Republic }\end{array}$ & 1,46 & 1,52 & 1,27 & 1,09 & 1,10 & 0,99 & 0,99 & 1,12 \\
\hline Slovenia & 1,49 & 1,59 & 1,61 & 1,30 & 1,18 & 1,06 & 0,98 & 0,95 \\
\hline $\begin{array}{c}\text { United } \\
\text { Kingdom }\end{array}$ & 2,44 & 2,51 & 2,51 & 2,42 & 2,20 & 2,30 & 2,20 & 2,07 \\
\hline $\begin{array}{c}\text { NATO - } \\
\text { Europe * }\end{array}$ & $\mathbf{1 , 6 9}$ & $\mathbf{1 , 7 0}$ & $\mathbf{1 , 6 4}$ & $\mathbf{1 , 5 6}$ & $\mathbf{1 , 5 3}$ & $\mathbf{1 , 5 1}$ & $\mathbf{1 , 4 7}$ & $\mathbf{1 , 4 3}$ \\
\hline
\end{tabular}

Source: NATO (2016), Financial and Economic Data Relating to NATO Defense, NATO Public Diplomacy Division, available at: http://www.nato.int/nato_static_fl2014/assets/pdf/pdf_2015_06/20150622_PR_CP_2015_093-v2.pdf

Furthermore, for a better understanding of the presented issues, based on the same data from the table above, we present the graphical represetation of the evolution of defense expenditures, as a percentage of the GDP, for these countries (Figure no. 2).

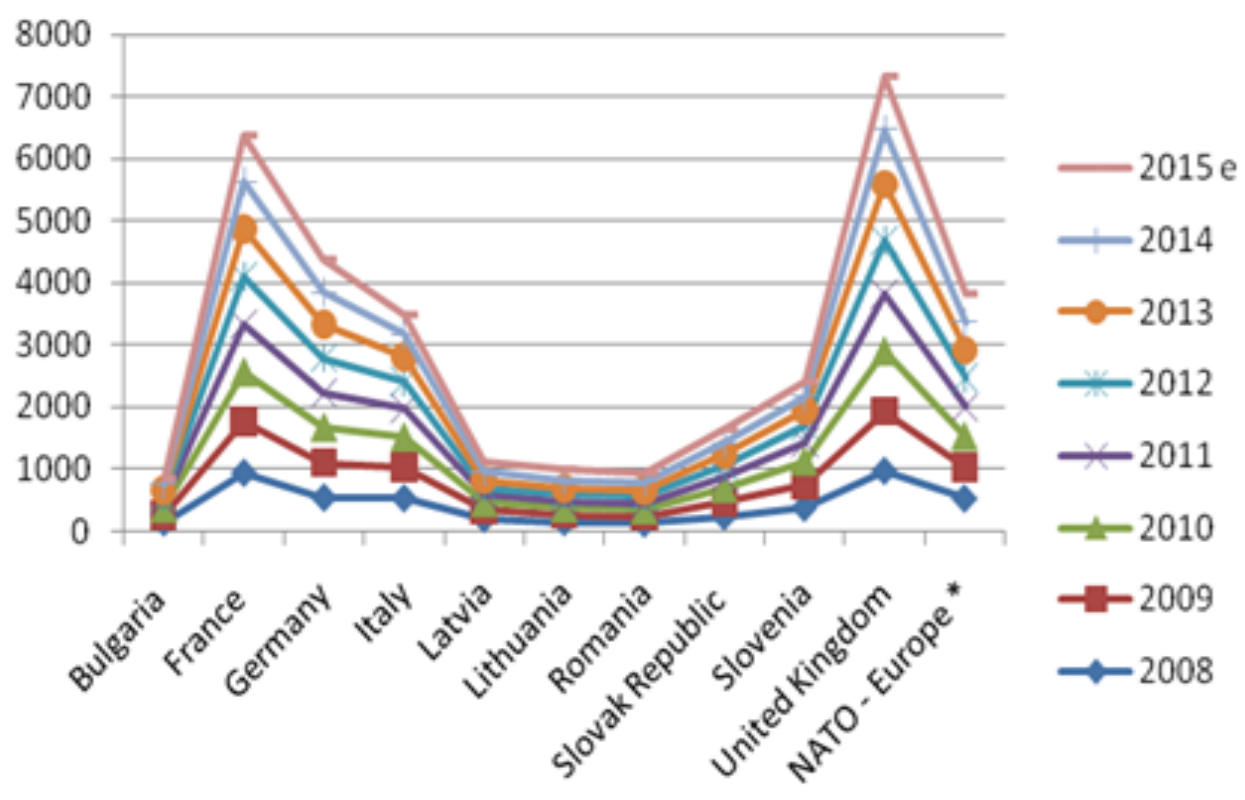

Figure no. 2. The evolution of defense expenditures, as a percentage of the GDP

Source: Drafted by authors, based on the data published by NATO (2016), Financial and Economic Data Relating to NATO Defense, NATO Public Diplomacy Division, available at:

http://www.nato.int/nato static fl2014/assets/pdf/pdf 2015 06/20150622 PR CP 2015 093-v2.pdf

The data highlighted in the figure above illustrate that, between the United Kingdom (the country with the highest percentage) and those that ranked last, the difference is much higher than one percentage point. Figure no. 1 reveals relatively easy the great differences between the amounts budgeted by the countries analyzed; however, the defense budget calculated as a percentage of the GDP does not reveal the same situation.

Moreover, during the analyzed period, there were no major variations for any of the states analyzed, but the situation recorded some change, downward by at least 10\%, during 2010-2012, which can reflect the status of the economy. In this period, there was registered a decrease in defense expenditures and in the US budget, for the first time since the fall of the Soviet Union. For 2015 , the analysis of the percentages allocated by each country, compared to the NATO-Europe average, highlight the greatest value of $2.7 \%$ of the GDP, allocated by the United Kingdom, and the lowest value of only 0.95 of the GDP, allocated by Slovenia, compared to an average of $1.43 \%$ of the GDP.

In addition, referring to the defense expenditures per capita (their evolution is shown in Table no. 3, in US dollars), it is revealed that we are dealing with an indicator reflecting, on the one hand, the governments' concern with the defense system and, on the other hand, the insight into the country's economic power. This indicator 
"Mircea cel Batran" Naval Academy Scientific Bulletin, Volume XIX - 2016 - Issue 1

Published by "Mircea cel Batran" Naval Academy Press, Constanta, Romania /I The journal is indexed in:

PROQUEST / DOAJ / DRJI / JOURNAL INDEX / I2OR / SCIENCE LIBRARY INDEX / Google Scholar / Crossref /

Academic Keys I ROAD Open Access / OAJI / Academic Resources / Scientific Indexing Services / SCIPIO

eliminates the influence of the population's different countries.

absolute size, facilitating comparisons between

Table no. 3. Defense expenditures per capita, in US dollars

\begin{tabular}{|c|c|c|c|c|c|c|c|c|}
\hline Country & 2008 & 2009 & 2010 & 2011 & 2012 & 2013 & 2014 & $\begin{array}{c}2015 \\
\mathrm{e}\end{array}$ \\
\hline Bulgaria & 145 & 115 & 110 & 92 & 94 & 103 & 95 & 89 \\
\hline France & 945 & 811 & 800 & 772 & 773 & 770 & 758 & 748 \\
\hline Germany & 543 & 557 & 566 & 555 & 570 & 533 & 524 & 521 \\
\hline Italy & 533 & 500 & 479 & 462 & 428 & 405 & 364 & 318 \\
\hline Latvia & 201 & 139 & 120 & 125 & 114 & 125 & 130 & 151 \\
\hline Lithuania & 149 & 124 & 105 & 103 & 103 & 109 & 131 & 175 \\
\hline Romania & 128 & 111 & 103 & 108 & 104 & 113 & 123 & 136 \\
\hline $\begin{array}{c}\text { Slovak } \\
\text { Republic }\end{array}$ & 243 & 239 & 210 & 185 & 189 & 172 & 187 & 207 \\
\hline $\begin{array}{c}\text { Slovenia } \\
\text { United } \\
\text { Kingdom }\end{array}$ & 380 & 369 & 377 & 306 & 269 & 240 & 228 & 227 \\
\hline $\begin{array}{c}\text { NATO - } \\
\text { Europe * }\end{array}$ & $\mathbf{5 2 9}$ & $\mathbf{5 0 2}$ & $\mathbf{4 9 3}$ & $\mathbf{4 7 5}$ & $\mathbf{4 6 4}$ & $\mathbf{4 5 7}$ & $\mathbf{4 4 9}$ & $\mathbf{4 4 6}$ \\
\hline
\end{tabular}

Source: NATO (2016), Financial and Economic Data Relating to NATO Defense, NATO Public Diplomacy Division, available at: http://www.nato.int/nato static fl2014/assets/pdf/pdf 2015 06/20150622 PR CP 2015 093-v2.pdf

As revealed by the above data analysis, the defense expenditures per capita in the UK and France are up to 7 times higher than those registered by the last ranked countries. If the expenditures of the first ranked countries exceed 800 US dollars/capita, as happens in the UK, and over 700 US dollars/capita in France, these values are limited at around 100 US dollars/capita in countries such as Bulgaria, Lithuania, Latvia or Romania, while the European average of this indicator is approximately 450 US dollars/capita.

The period considered (2008-2015) shows a decrease in these indicators, for all the countries under discussion, and for NATO and Europe average.

The distribution of expenditures for equipment categories (Table no. 4) is another indicator that provides an insight into the each country's priorities regarding the allocation of resources in national defense issues. The data source delineates four expenditure categories: infrastructure, personnel, equipment and other expenditures.

Table no. 4. Distribution of defense expenditures by major categories (\%) 2015

\begin{tabular}{|l|r|r|r|r|}
\hline Country & Equipment & Personnel & Infrastructure & Others \\
\hline Bulgaria & 3,2 & 71,8 & 1,7 & 23,2 \\
\hline France & 25 & 47,8 & 2,8 & 24,4 \\
\hline Germany & 13,3 & 47,8 & 3,6 & 35,3 \\
\hline Italy & 12,5 & 80,3 & 0,9 & 6,2 \\
\hline Latvia & 10,3 & 51,8 & 6,9 & 31 \\
\hline Lithuania & 20,1 & 49,3 & 4,5 & 26,1 \\
\hline Romania & 14,6 & 66,4 & 1,5 & 17,5 \\
\hline $\begin{array}{c}\text { Slovak } \\
\text { Republic }\end{array}$ & 18 & 61 & 2,4 & 18,6 \\
\hline Slovenia & 18 & 80,7 & 1,1 & 17,5 \\
\hline $\begin{array}{c}\text { United } \\
\text { Kingdom }\end{array}$ & 23,4 & 38,1 & 2,6 & 35,9 \\
\hline $\begin{array}{l}\text { United } \\
\text { States }\end{array}$ & 26,1 & 36,4 & 1,7 & 35,7 \\
\hline
\end{tabular}

Source: Drafted by authors based on the data published by NATO (2016), Financial and Economic Data Relating to NATO Defense, 371

DOI: 10.21279/1454-864X-16-I1-061

(C) 2015. This work is licensed under the Creative Commons Attribution-Noncommercial-Share Alike 4.0 License. 


\begin{abstract}
"Mircea cel Batran" Naval Academy Scientific Bulletin, Volume XIX - 2016 - Issue 1 Published by "Mircea cel Batran" Naval Academy Press, Constanta, Romania /I The journal is indexed in: PROQUEST / DOAJ / DRJI / JOURNAL INDEX I I2OR / SCIENCE LIBRARY INDEX / Google Scholar / Crossref I Academic Keys / ROAD Open Access / OAJI / Academic Resources / Scientific Indexing Services / SCIPIO
\end{abstract}

The above table shows that the majority of funds are allocated for personnel expenses, situation typical of all the surveyed countries, the total of these distributions emphasizing Italy, Slovenia, and Bulgaria. The second position in terms of this distribution is different, being either held by other expenditures (including maintenance, research and development expenses, etc.) as in the UK (35.9\%), Germany (35.3\%), Lithuania (26.1\%) or by equipment expenditures, as happens in France (25\%) and Italy (12.5\%).

Regarding the percentage allocated to infrastructure, it has the lowest percentage in all the analyzed countries, ranging between $6.9 \%$ in Latvia and $0.9 \%$ in Italy.

\section{The national context}

Romania's defense policy aims at achieving the national and international commitments as a NATO member and as a member of the European space. Romania's defense policy objectives are (Defence White Paper, 2015):

$\checkmark$ Equipping military forces;

$\checkmark$ Participating in theaters of operations;

$\checkmark$ Fulfilling training standards;

$\checkmark$ Structural and functional improvement of the Army's operational management system;

$\checkmark$ Providing the communications and

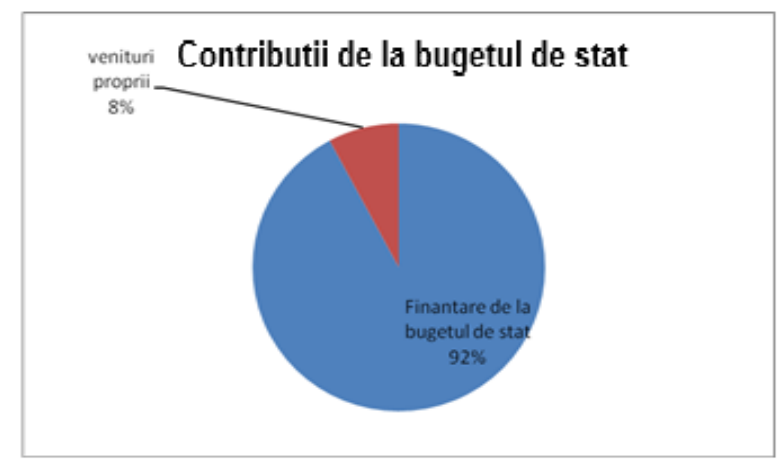

Figure no. 3. Contributions from Romania's state budget for 2016

Source: Ministry of National Defense budget, approved by law no. 339/2015 on State Budget 2016

For 2016, funding from the state budget represents $92.14 \%$, plus the country's own revenues $-7.86 \%$ (MApN, 2015). It is noteworthy informatics support necessary to the performance of the Army's operational management;

$\checkmark$ Compatibilizing Romania's structures and equipment with those of NATO Member States and cooperating with the later by exchange of information and joint operations.

The Strategic Plan of the Ministry of National Defense (MApN, 2010) states that "planning and programming of financial resources for defense are made consistent with the overall objectives of the Ministry of National Defense and with the priorities defined in the provisions of the national defense strategy, defense policy guidelines, established by the government program, and in accordance with NATO's Strategic Concept and NATO Ministerial Directive, the funding-based programs underlying the planning, programming and budgeting process". Payment of the obligations assumed to the North Atlantic Alliance and to the European structures is primary, compared to other expenditures.

In our country, national defense funding is made (Figure no. 3) mainly from the state budget, from the country's own revenues (services, rents, organizing diving courses, vehicle repairs, roadworthiness) and from external funds.

that these (military) expenditures are of two types:

a) direct expenditures, comprising maintenance expenditures of the Army within the country or in military bases from other countries, materialized in the procurement of goods and services, providing equipment, weapons and combat equipment;

b) indirect expenditures, related to the consequences of war or to the preparation of future confrontations.

From a graphical perspective, defense expenditures, as a percentage of Romania's GDP, are represented as follows (Figure no. 4). The figure above highlights the evolution of the percentage of the GDP allocated to defense, revealing a return in 2015 to the values from 2008, without reaching higher values, such as those from 2005. After the accession to NATO, the money allocated to this sector was increasingly fewer and fewer, until 2013, when our country proposed a gradual supplementation of the defense budget. The lack of budgetary support has affected the transformation process defined and detailed in the Romanian Army's Transformation Strategies (Government of Romania, 2013). The figures presented in our paper reveal that the defense budget was a priority only when Romania joined NATO. 
"Mircea cel Batran" Naval Academy Scientific Bulletin, Volume XIX - 2016 - Issue 1

Published by "Mircea cel Batran" Naval Academy Press, Constanta, Romania /I The journal is indexed in:

PROQUEST / DOAJ / DRJI / JOURNAL INDEX I I2OR / SCIENCE LIBRARY INDEX / Google Scholar / Crossref /

Academic Keys I ROAD Open Access / OAJI / Academic Resources / Scientific Indexing Services / SCIPIO

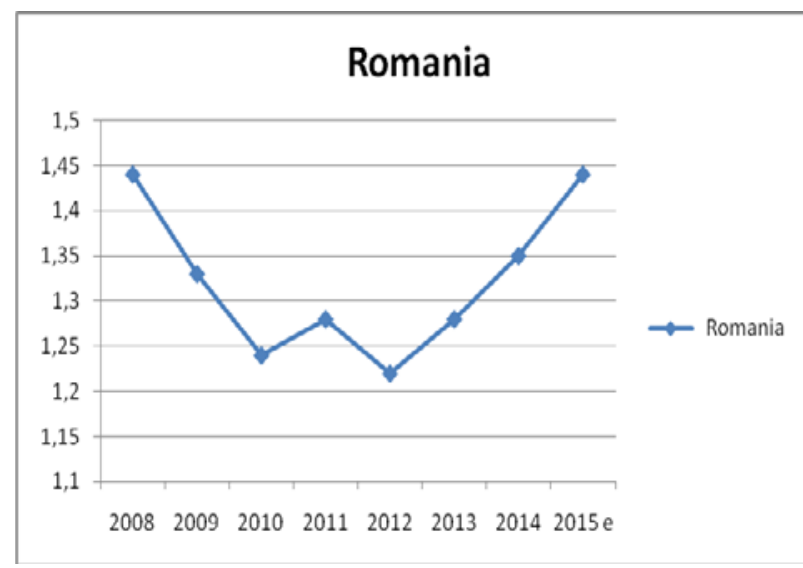

Figure no. 4. Defense expenditures, as a percentage of Romania's GDP

Sursa: NATO (2016), Financial and Economic Data Relating to NATO Defence, NATO Public Diplomacy Division, disponibil la:

http://www.nato.int/nato_static fl2014/assets/pdf/pdf_20 15 06/20150622_PR_CP_2015 093-v2.pdf

Fulfilling the role assumed by Romania is closely correlated with the resources allocated through the Ministry of Defense and they require supplementation, in order to reach the level of $2 \%$ of the GDP, in accordance with NATO recommendations, as stipulated recently in the National Policy Agreement on the increase of defense financing (Romanian Presidency, 2015). In addition, the target is to maintain this funding level of the Army for 20172027 and, where financial resources allow it, to increase this percentage, depending on the security needs and obligations that Romania can assume. The Agreement also provides support for multi-annual budgetary planning of military expenditures, in order to ensure the predictability of the procurement policy of the Romanian Army with modern combat equipment, and the development of cooperation projects between the national defense industry and specialized companies from other countries.

On the other hand, the allocation of $2 \%$ of the GDP involves taking into account the income from the capitalization of tangible and intangible surplus assets from the MND patrimony and those made in the provision of services to legal entities or natural persons, under the law. The failure to budget this percentage would hinder or delay the achievement of the above-mentioned objectives, triggering consequences on the assumed targets and deadlines.

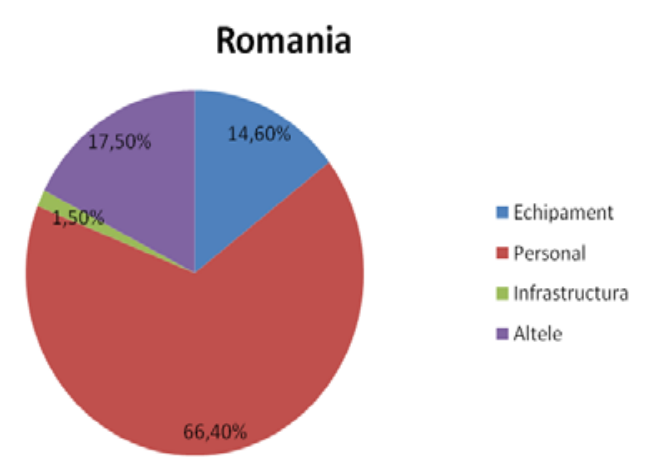

Figura nr. 5. Distributia cheltuielilor de aparare pe categorii principale (\%) 2015

Sursa: NATO (2016), Financial and Economic Data Relating to NATO Defence, NATO Public Diplomacy Division, disponibil la:

http://www. nato.int/nato static fl2014/assets/pdf/pdf 20 15_06/20150622_PR_CP_2015_093-v2.pdf

Regarding the distribution of defense expenditures per categories (Figure no. 5), it is revealed that the highest percentage, i.e. $66 \%$, is assigned to total personnel expenditures; $14 \%$ is assigned to equipment expenditures and the infrastructure has the lowest percentage, i.e. $1.5 \%$. The remaining $17 \%$ of total defense expenditures is assigned to other activities, such as maintenance and research and development expenditures.

All these lead us to the conclusion that Romania's national defense system should be reconsidered, especially as a state supplier of international security, in terms of efficiency.

\section{CONCLUSIONS}

For each country, national defense is an important component of the strategy to ensure national security. At the same time, it expresses the content of the state's external function wherefore, each year, large financial assets are budgeted. These allocations ensure the maintenance and operation of the national army, the participation in various military alliances, the operation of military bases on foreign territories, military aid to other countries. The analysis performed in the paper shows that there is a strong correlation between the domestic performances of the countries under discussion and the organization of the national defense. The economic performance of the top countries from the previously presented rankings set a measure on the indicators with expenditure values over the average, in order to ensure the defense system. Romania, by its membership with full rights and obligations in the EU and North Atlantic structures, which guarantee its economic progress and security, must strive in order to meet the demands in security, defense, economic 
"Mircea cel Batran" Naval Academy Scientific Bulletin, Volume XIX - 2016 - Issue 1

Published by "Mircea cel Batran" Naval Academy Press, Constanta, Romania /I The journal is indexed in:

PROQUEST / DOAJ / DRJI / JOURNAL INDEX / I2OR / SCIENCE LIBRARY INDEX / Google Scholar / Crossref /

Academic Keys / ROAD Open Access / OAJI / Academic Resources / Scientific Indexing Services / SCIPIO

and social development, diplomacy and, not least, scientific and technical progress. Romania's budgetary allocation for defense must allow it to meet the requirements arising from its commitments as a full member of North-Atlantic and EU structures. Given the budget crisis triggered by the economic and financial crisis, Romania failed to provide a sufficient allocation of its resources, as proposed.

\section{ACKNOWLEDGEMENT}

The authors would like to express grateful thanks the anonymous reviewers for their encouraging and constructive comments.

\section{BIBLIOGRAPHY}

[1]. Atanasiu Mirela, Implicaţiile participării României la dezvoltarea capabilităţilor în cadrul multinaţional organizat de NATO şi UE prin iniţiativele „SMART DEFENCE” şi „POOLING AND SHARING” asupra revizuirii Strategiei de transformare a Armatei României, Editura Universitatii Nationale de Aparare „Carol I", Bucuresti, 2014.

[2]. Dutu P., Sarcinschi A., Bogzeanu C., Apararea nationala, intre viziune si realitate, la inceput de mileniu, Editura Universitatii Nationale de Aparare „Carol I”, Bucuresti, 2013.

[3]. MApN, 2010, Planul Strategic al Ministerului Apararii Nationale 2010-2013, http://www.mapn.ro/despre mapn/informatii_generale/documente/plan_2009.pdf

[4]. NATO, Financial and Economic Data Relating to NATO Defence, NATO Public Diplomacy Division, 28 January 2016, disponibil la:

http://www.nato.int/nato_static_fl2014/assets/pdf/pdf_2015_06/20150622_PR_CP_2015_093-v2.pdf

[5]. MApN, 2016, Document-Sinteză privind politicile și programēe bugetare pe termen mediu pentru anul 2016 și perspectiva 2017-2019, disponibil la: http://www.cdep.ro/pdfs/buget/2016/Anexa\%203/Ministerul\%20Apararii\%20Nationale.pdf

[6]. Guvernul României, Programul de guvernare 2013-2016, Bucuresti, 2011

[7]. Camera Deputaţilor, Document sinteză privind priorităţile strategice pe termen mediu pentru anul 2014 şi perspectiva 2015 - 2017, disponibil la: http://www.cdep.ro/proiecte/2013/500/10/4/318.pdf.

[8]. CSAT, 2015, Programul privind transformarea, dezvoltarea si inzestrarea Armatei Romaniei pana in anul 2027 si in perspectiva

[9]. Presedentia Romaniei, 2015, Acord politic naţional privind creșterea finanţării pentru Apărare, http://old.presidency.ro/static/Acordul\%20politic\%20national\%20privind\%20cresterea\%20finantarii\%20p entru\%20Aparare.pdf

[10]. Strategia Naţională de Apărare a Ţării pentru perioada 2015-2019 "O Românie puternică în Europa şi în lume", 2015, http://www.presidency.ro/files/userfiles/Strategia_Nationala_de_Aparare_a_Tarii_1.pdf

[11]. Guvernul României, Carta Albă a Apărării, aprobată în şedinţā din $09.09 \overline{2} 01 \overline{5}$. 